\title{
Charismatic Kiais Perception Of The Construction Cement Plan in Rembang
}

\author{
Ahmad Hariyadi ${ }^{1}$, Joko Setiyono ${ }^{2}$

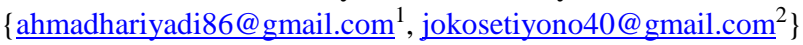

${ }^{1,2}$ IKIP PGRI Bojonegoro, Indonesia

\begin{abstract}
This study aims to describe the perceptions of charismatic scholars in Rembang Regency towards the construction of a cement factory. This study used phenomenology qualitative approach. Charismatic Kiais included in the Rembang Regency area, from Sarang sub-district, Lasem sub-district and Rembang sub-district. The results of this study indicate that charismatic kiai have different views on the construction of a cement plant in Rembang, between supporting and rejecting. The supporting cement factories due to economic growth factors, as a supporter of progress, and rejecting cement factories due to damaging the environment and reducing socio-cultural comfort. The conclusion of this study, are different views of Charismatic Kiais create polarization of society with a strong view of the cement plant in Rembang.
\end{abstract}

Keywords: perception, kiai charismatic, polarization.

\section{Introduction}

The conflict on cement Rembang which happened in Gunem Rembang since 2010 created the opinion toward polarization among society. It is including the religion leader and kiai in Rembang, Central Java. From this phenomenon, most of the society are split. There are pro and contra inside them. Moreover, there are people who support and unsupported this situation. It is because they rejected the cement factory based on calculation. Where, it has the large and the big exploitation power scale. The society's opinions show on the research conducted by [1], [2]. They said if the conflict on cement factory Rembang is the sequence of conflict to the small scale mining company which exists from 1996. Therefore, there is negative impact reaches the society if they build the big scale factory.

The rejection who comes from society to the negative impact of cement factory in Gunem Rembang represents the disagreement society with it. However, they must concern with the low society around the factory. It means the government need to make the policy so that the people who live around the factory can spared from the negative impacts as the results. According to [3], one of the factor why the society does not accept the cement factory is because of the point of view differences from the leader religion. It also covers the kiai charismatic in facing the cement factory building in Gunem Rembang. From that different point of view, there is the deep and strong differences as the outcome in the argument based on the opinion and belief by them. From this pro and contra, the kiai charismatic can guide the society's pion of view with their own belief. However, there are some polemics continuity in conflict until now. The role of ideal kiai charismatic like in [4] figure out as the place of the problem solving in society in any cases. It is identic with the openness, egalitarian and inclusiveness, but its role are not balanced yet. 
The perception differences of the kiai charismatic in Rembang shows the science objectivity. It can be seen from Suharko (2013a, 2016b) about the society perception to the cement factory establishment which has two different point of view. The first, it refers to the economic objectivity. The other is on the environment conservation. By seeing those reason, the effects from those point of views brings the low society's opinion and drives the belief about the polarization differences. The aim of this research is to analyze the kiai charismatic perception in Rembang district to the cement factory establishment.

\section{Review Related Literature}

\subsection{The Charismatic Kiai Ontology}

[4], through the charismatic which attached in him, the kiai is as the imam in ubudiyyah. The society often asked him to come to solve the problem around environment. This activity makes him stronger in his role because people assume if he brings the blessings. The example is, he is asked to heal the people, gives the religion lecture, pray for those who sell the goods in well, etc.[5] concluded if the kiai and santri's life make the pesantren has multidimensional Function. He is not only has the role as the imam in ubidiyah and religion ceremony, but also to solve the problem in society. [4] said if the role of kiai to conserve the religion tradition produced a subculture pesantren. It is as the socio culture movement in santri community which is happening since long time. The kiai is the educator to the santri and as the good example for them from the whole society. He is also as the vital organ in pesantren which has three main roles such as kiai, santri and pondok.

The role of kiai charismatic from the educational and religion aspects based on Qomari [6] is as the pesantren tradition. It is the foundation, where between kiai and around society cannot be separated. [7] stated if the kiai charismatic style has the weakness and advantage. Among others, the weakness is if that phenomenon is adopted continuity. Kiai becomes the leader of the followers. He is also as the figure to the society which has implication to the basic religion on the act. So that, the people only can listen and obey when he said something. [8] stated if kiai is a status which has to be honored. He has all the role and played it in society. Then, the character and the leadership of kiai show how strong the proficiency and shower personality in governing the pesantren and society. Those can be seen in how he builds the role strategy as the non-formal leader society through the intensive communication. This is not new inside the environment, even since in the colonialism where the role of kiai is stronger than now.

As the main pivot from the social dimension, culture and the traditional Islamic in society religion. The pesantren develops a subculture in sociological anthropology as the society pesantren. There is five basic elements inside pesantren as the traditions such as the santri (the students who learns Qur'an from kiai), pondok (the boarding house to the santri), mosque, the old books teaching, and the kiai [9] [10]. For pesantren society, the kiai handles a central role in uniting and saving the people from the threat power outside. Ibnu Hajar [11] stated if the role of kiai can be rendered into some instances. First, he spreads and maintains the doctrine and the Islamic values. As people know, the pesantren is one of the main Islamic values separation. Second, he has the control on society. It can be the awareness effort to the society behavior which is far from Islamic values. Third, he solves the problem inside society as the domain, where the kiai as the problem solver to the problem facing by them. The problems are not only about religion case, but also can be on how to farm, the household, etc. fourth, he is as the agent of social movement. From those definition, point one until three flow on the big 
social change. The change is on the life dimension better, especially on the religion differences.

\subsection{The perception of charismatic kiai on the development}

The life objectivity of reality about the objectivity and the subjectivity are shown with the way to differ and how to assess freely. On the other hand, all the people are acceptable to use those perceptions. Those can be seen on the life reality from the belief tendency. If that perception has the freely assessment so the charismatic will has the thought dualism differences from the other religion characters.

It is in line with Suharko $(2013 a ; 2016 b)$ if the society perception to the cement factory establishment in Pati has the different point of view. Each character has their own strong perception in the economic objectivity conservation. [2], [12] argued about the society point of view on cement factory in Rembang. It has the influence in the knowledge paradigm shifting and has the impact in the differences of religion leader point of view.

\section{Research Methodolody}

This research used the qualitative method with [13] approaches. In this research, the researchers tried to show the kiai perception which is as the opinion observed carefully. In this case. Some kiai do not release the rational idea about the phenomenon happened in society. Otherwise, the kiai has a relationship with political ideologiy, either PPP or PKB. The phenomenon in this research should be understood deeply. Moreover, the meaning from the kiai's utterances must be processed and ponder carefully so that there will be rendered better and there is no ambiguity. The method of data collection used the deep interview. It also applied the hermeneutic analogy or deeply interpretation. The researcher also used some relevant documentation such as the media and the use of informant.

\section{Result and Discussion}

The results of this research shows in line with [2] if one of factor influence the social movement in Rembang to the rejection of cement factory establishment is the differences of point of view from the educational leader and religion. From this phenomenon, the society wants to go and know deeply about the real truth. The social movement in Rembang is not only because of the conflict, but it is to drive the condition to be the better direction.

For the general perception, there is economic rationalism corner against the objectivity as the impact of cement factory. However, the real truth becomes the domain refers to the universal truth (the long-term truth). The real truth rationalism is still take place until now, where the society still can keep on the trough on their own perception.

The society has the rejection perception on the cement factory like the economic principle. It is not as the short-time interests. People who is as the conservation clan prefer in how the basic continuity can be useful to long-term and for the posterity in the future. It represents not to reject the cement factory establishment, but how the establishment brings the benefits to the society around with the humanism and creative manner. Those drive the society not to damage the nature so that the cement factory building can be blessings.

The blessings based on the kiai charismatic is divided by two categories. The first is giving benefit to the economy and the second is not damage the nature. The economic beneficiary in line with the religion leader point of view who support the cement factory establishment will 
be followed by the society who agree with it. While, the damage environment is with the society who disagree with it.

The differences of epistemology from the kiai charismatic about the cement factory in Rembang is shown with how the point of view and perception are uttered on the argumentation like the following utterances from the kiai charismatic from Lasem:

"The cement factory is not about economic need, but it must consider the damage on the nature and the socio culture. The economic perception is as the prosperity point which must be reviewed. Moreover, there is also the though reconstruction from the various parties. The cement factory establishment should not become the bad impact for the ecosystem. It has to be reviewed such as the farm creativity and the tourism. Then, the cement factory must bring the new culture. It also brings the contradiction with the culture society around". (Interviewed on 1 march 2019)

The blessing on the ontologies review has the similarities to the kiai charismatic in Rembang district. They do not make the differences as the big problem, but it is not with the society itself.

\section{Conclusion}

The ontology which is explained from the blessing by the kiai charismatic brings the differences. It also makes the polarization on society. Then, it creates the groups on society. The blessings epistemology idealism must be transferred to the society so that the knowledge transformation or the real truth can be understood and responded by the society.

\section{References}

[1] S. Puryanto and Suyahmo, "Urban Social Movement in Indonesia," Int. J. Sci. Res., vol. Vol. 75, no. 1/1, 2019.

[2] S. Puryanto, D. S. Liesnoor, Suyahmo, and M. Jazuli, "Factors Cement Mining Conflit in Rembang Central Java, then Emerged Social Movement," Proceeding 7th Glob. Conf. Bus. Soc. Sci. Srilanka, 2018.

[3] S. Puryanto and D. Susanto, "Konflik dan Gerakan Sosial di Rembang," 2019.

[4] Sukamto, Kepemimpinan kiai dalam pesantren. Lp3es, 1999.

[5] A. Fadhilah, "Struktur dan Pola kepemimpinan kyai dalam pesantren di Jawa," Hunafa J. Stud. Islam., vol. 8, no. 1, pp. 101-120, 2011.

[6] M. Qomar, Pesantren: dari transformasi metodologi menuju demokratisasi institusi. Erlangga, 2002.

[7] A. Hariyadi, R. Rustono, S. E. Pramono, and H. Yanto, "Charismatic Leadership of Kiai in Developing an Organizational Culture of Islamic Boarding School," J. Educ. Dev., vol. 6, no. 1, pp. 44-53, 2018.

[8] M. Ziemek, Pesantren dalam perubahan Sosial. Perhimpunan Pengembangan Pesantren dan Masyarakat (P3M), 1986.

[9] D. Zamakhsyari, "Tradisi Pesantren: Studi tentang pandangan hidup kyai," Jakarta PT. Pertja, 1985.

[10] Z. Dhofier, Tradisi pesantren: memadu modernitas untuk kemajuan bangsa. Pesantren Nawesea Press, 2009.

[11] I. Hajar, Kiai di tengah pusaran politik: antara petaka dan kuasa. IRCiSoD, 2009.

[12] S. Puryanto, "Factors Mining Conflict; Local Perception (Cement Mining Conflict in Rembang Central Java Indonesia),” Int. J. Sci. Res., vol. 7, no. 11, pp. 1356-1359, 
2018.

[13] A. M. Huberman, M. Miles, and J. Saldana, "Qualitative data analysis: A methods sourcebook.” Thousand Oaks, California: Sage Publications, Inc, 2014. 